\title{
Decision making within dual career households: An analysis of the impact of child rearing upon career priorities and earnings
}

\author{
Irene Hardill * and Robert Watson **
}

\begin{abstract}
This paper investigates the impact of child rearing upon male and female labour market participation rates and earnings within 130 dual career households. The results indicate that female earnings and participation rates in households with children are significantly lower than both comparable males and females without children. There was no evidence of significant gender differences in pay within (the predominantly, younger) households without children or between these and males in households with children.
\end{abstract}

Keywords: gender; households; careers and child rearing; decision-making

*Department of International Studies, The Nottingham Trent University, Clifton Lane, Nottingham NG11 8NS; Tel: 0115848 3305; E-Mail: Irene.Hardill@ntu.ac.uk

**Department of Accounting \& Finance, University of Glasgow, Glasgow, G12 8LE, UK. Tel: 0141330 6693; E-Mail: R.Watson@accfin.gla.ac.uk 


\section{Decision making within dual career households: An analysis of the impact of child rearing upon career priorities and earnings}

\section{Introduction}

In 1971, shortly before the introduction of equal pay legislation in the UK, just over half of women in the 25 to 44 years age range were economically active. Currently the proportion is over three-quarters (Hardill et al, 2001), which indicates the radical economic and social transformation of women's lives over the intervening period. ${ }^{1}$ Women's participation in the labour market cannot, however, be understood in isolation from their position in kinship and family structures, and their relationship to childbearing and reproduction (Horrell and Humphries, 1995). ${ }^{2}$ Many studies have examined the effect that equal pay legislation and other public policy initiatives, such as the introduction of maternity benefits, parental rights and

\footnotetext{
${ }^{1}$ In 1974 in the UK for example, women comprised 2 per cent of managers, by 1998 the proportion was 18 per cent (ONS, 1998, 31). The proportion of women in some professional occupations has also increased, accounting in 1998 for 64 per cent of teaching professionals; 33 per cent of solicitors holding practising certificates in England and Wales (compared with 20 per cent in 1988); 24 per cent of barristers in 1998, compared with 14 per cent in 1987. But in 1998, 88 per cent of architects, town planner and surveyors were men; 71 per cent of business and financial professionals and 93 per cent of judges (ONS, 1998, 32) But women account for half of all university enrolments (Court, 1995).

2. In the Spring of 2000 the problems of balancing work and home were placed centre stage when one of the UK's most 'visible' dual career couples - Prime Minister Tony Blair and Cherie Booth - fourth child was born. Tony Blair took a couple of weeks leave but prime carer, Cherie Booth withdrew from the labour market for several months of maternity leave (longer than the statutory period). With the impending birth of a child a woman has to instruct her employer about maternity leave but she and her partner have to reassess home and work. This was very publicly done in the British press in spring 2000 in the case of Tony Blair and Cherie Booth.
} 
nursery provision, etc., have had on women's formal labour market participation, the power balance within households, and on the sharing of the tasks of social reproduction (Blossfeld and Drobnic, 2001; Gregson and Lowe, 1994; Momsen, 1999). What appears to be accepted is that, despite almost 30 years of equal pay legislation, significant gender inequalities in earnings persist because the unequal allocation of domestic responsibilities has meant that women's ability to commit to the labour market has been constrained, spatially and temporally, often resulting in having to work part-time. Thus, whatever the intentions of the individuals concerned, the unequal allocation of domestic responsibilities appears to reinforce the "traditional" fundamental inequalities in economic power between male and female partners within households (Arber 1999; Ginn and Arber, 1995; Pahl, 1989).

In this paper we focus on dual career households, who form part of a growing minority of households, between 10-20 per cent of all couples in Britain, the USA and Canada, in which both partners are pursuing careers (Hakim, 2000, 111). For the purposes of this paper, dual career households are defined as those in which both partners (that is, two heterosexual adults living as a couple in a two person or larger household) are in managerial and administrative, professional and associated professional and technical occupations; the types of occupation which tend to place particular demands on the individual and emphasise commitment (Erikson and Goldthorpe, 1992, 42). While the number of childless dual career households is increasing, about two-thirds of dual career households have had children and so will have had to confront the dual problems of deciding on career priorities and the allocation of child care and other domestic responsibilities. As suggested above, the unequal allocation of such responsibilities 
means that though women in dual career households have income from paid work, this typically does not result in an equality of economic power vis à vis their partner (Arber, 1999, 177). Even so, Phillibeer and Vannoy-Hillier (1990) have shown that there are many mutual advantages to spouses within dual career couples beyond simply the additional income which may outweigh the practical inconvenience of having no full-time homemaker, especially when many have no children living at home. Shared social capital, intellectual and work interests can allow spouses greater achievements and upward mobility than they would achieve alone.

Men and women in dual career households have to make decisions about career priorities after childbirth with many factors in mind, including levels of maternity pay; immediate loss of earnings if a career break is taken; availability of affordable childcare; desire to look after one's child oneself; family support etc. They face the problem of co-ordinating two, often highly demanding and time consuming careers and therefore such households are likely to experience tensions whenever domestic responsibilities, such as childcare, may necessitate one or both partners to divert time and energy from pursuing their careers. Childbirth is one of the most physically and emotionally demanding periods of a woman's life, but since the 1970s British women have had statutory maternity rights (Table 1) but these rights are limited when compared with other EU countries (Dex and Joshi, 1999; Drew, 1998). Gender equality in incomes remains resilient as women's pay/hours drop relative to men's once they have children due to the continued unequal division of the tasks of social reproduction (Arber, 1999, 177; Folbre, 1994, 51; Ginn and Arber, 1995; Hochschild, 1997; Jacobsen, 1994, 85; Jacobsen and Rayack, 1996). 


\section{TABLE 1}

In this paper we investigate the impact that child rearing has upon the within household distribution of earnings in respect of a sample of dual career households located in the East Midlands region of the UK. An individual's current level of earnings is the outcome of many decisions taken over their life-course, though various institutional constraints and cultural expectations inevitably have a significant impact on these apparently "free choices" (Deaux and Major, 1987). Generally, relationships formed around family and co-habitation/marriage imply a large element of “common interests” in order to override individual competitiveness and demands for mobility when decisions concerning the allocation of domestic responsibilities have to be made. Occasionally therefore one or more partners may be expected to sacrifice (give a lower priority to) their own particular career interests to invest more resources in the collective project called “family” (Beck and Beck-Gernsheim 1995, p.52). Indeed Beck and BeckGernsheim argue that "every marriage consists of two marriages, the husband's and the wife's” (ibid, p.62).

High status and well-paid careers are predominantly full-time, highly demanding, competitive and “progressive” (Evetts, 2000, 60), with part-timers and those with significant career "breaks”, in consequence, often regarded by employers as less dedicated, less professional and more "time deviant” (Epstein et al, 1999). Thus, whenever significant child rearing responsibilities limit their full participation in the labour market, women's ability to pursue careers and their earnings potential can be expected to be particularly constrained spatially and temporally (Hanson and 
Pratt, 1995; Jarvis et al, 2001; McKie et al, 1999). Moreover women in dual career households, even childless women, are more likely to be in relationships where the male career takes precedence in location and mobility decisions, and she is the 'trailing spouse' with the 'follower'/ secondary career, which is unplanned and erratic (Bruegel, 1996; Hardill et al, 1997). Typically for the trailing spouse, household migration is not associated with positive career developments. Thus, both past and anticipated household migration and child rearing have for a long time been recognised as producing significant dampening influences upon the life cycle wage evolution of married women (Mincer, 1978, 771).

This paper analyses the impact of child rearing upon male and female earnings and participation rates within dual career households. The Personnel Directors of five organisations based in Nottingham in the East Midlands were approached to help in the identification of dual career households - including health service and higher education establishments, a major bank, and two large market oriented private sector manufacturing companies (one engaged in the food and drink industry and the other in pharmaceuticals). In this way we gained access to staff in a relatively comprehensive range of managerial, professional and associated occupations. Each of the participating organisations has a different organisational structure, and hence the internal labour market conditions are somewhat different. In each of the dual career households identified, at least one partner is employed at a Nottingham base by one of the five employers. The other partner could work for any employer (or indeed work in a self-employed capacity) in any location. 
A semi-structured self-completion questionnaire survey (for a fuller discussion of the methods see Hardill et al, 1999) was first undertaken. The questionnaire schedule was in three parts, with sections on each career, including jobs held and places of residence since 1980, educational attainment and 'their' career (general household information). In most cases the female partner completed the section on 'their' career. An analysis of this longitudinal dataset for 130 households is presented in this paper. A sub-set (thirty households) of those who completed the survey element of the research also participated in the in-depth qualitative interviews. Each partner was interviewed separately (Pahl, 1989; Valentine, 1999). We also draw on the qualitative interview material in this paper.

Most of the face-to-face interviews took place in their homes, and were biographies - life narratives - of a very intense nature (Sizoo, 1997). The interview schedules are not a factual record but texts structured by the interviewees interests, commitments, quirks etc, 'constructed subjectivity' (McLaughlin, 1997, 13). The intention of the face-to-face interviews was not to collect detailed quantitative information, but rather to provide insights into the factors taken into account by dual career households relating to juggling work and home. We have used the interview schedules to facilitate the recognition of the household in terms of a dynamic network of negotiated relations (social, cultural, emotional and economic) exploring issues of mobility and power (Hardill, et al 1997). In many instances the accounts of their lives together were told in very different ways by the two partners, and on the homeward journey we recounted the interviews comparing and contrasting each version of 'their' story, especially in the households 
with children. Some male partners did not mention the children, while in all the interviews with women who had been mothers, issues relating to their offspring featured prominently.

Our empirical analysis draws first on the quantitative questionnaire data relating to 130 households and this is followed by an analysis of the qualitative interview material. We find that the average earnings and hours spent at work by the female members of the surveyed households are significantly lower than comparable males, though the differences are not statistically important in respect of (the predominantly, younger) households that have never had child rearing responsibilities. The earnings and hours of work of females with children, irrespective of whether or not the children remain dependants or have left the household (“empty nesters"), are however significantly lower than their male partners. The males in these households also have significantly higher earnings than other males, though the difference is largely accounted for by other earningsrelevant factors such as their greater average age, longer job tenure and the slightly greater number of hours spent at work.

The results suggest that, although child rearing appears to permanently alter the within household distribution of earnings (and hours of paid work), total household income and hours of outside paid work seems not to be materially affected. Thus, whilst in principle child rearing responsibilities could involve both partners reducing their labour market participation and earnings by similar amounts, in practice it appears usually to result in the dual career household opting, as in the “traditional male breadwinner" household, to prioritise the male partner's career and earnings potential. A consequence of this within-household gender specialisation and the prioritising of the 
male's career appears, however, to be that the earnings of the females in dual career households tends to decline significantly relative to that of their male partners. Follow-up interviews with a subset of the surveyed households also indicated a widespread recognition that child-rearing responsibilities are (and should be) predominantly allocated to female partners and that this was likely to have negative consequences in respect of their career prospects and earnings potential.

\section{The Data and Descriptive Statistics}

In Table 2 we provide descriptive statistics relating to the pay, hours of work and the various job and personal (i.e., human capital) characteristics of the male and female partners in all 130 dual career households. ${ }^{3}$ We also provide comparative statistics relating to the 47 households that have never included children, the 33 households currently still containing one or more dependent children and the remaining 50 households that did once include, but do not currently contain, dependent children (the “empty nesters”).

\section{Table 2}

3. We actually obtained information relating to 136 households. However, of the 272 individuals involved, 4 females and 2 males were temporarily unemployed at the time of the survey. As information on these 6 individuals' pay and hours of work was not available, the empirical analysis reported in tables 1 and 2 have been based on the 130 complete dual career households. 
The three columns of Table 2 relate to the 130 male, female and dual career household averages. As can be seen from Table 2, the males are on average 2 years older and have almost 2 years longer job tenure than their female partners and are paid on average almost £9,000 per annum more. On average, the males claim to work almost 10 hours per week longer than the females in the sample. The relative proportions of males and females with at least a degree-level and/or a professional qualification are virtually identical at $86.0 \%$ and $85.2 \%$ respectively. However, in terms of the sectors and the occupations of the males and females there are some notable differences. A significantly higher proportion of males are employed within the higher education sector (38.2\% versus $26.4 \%$ ), and are in managerial (30.8\% versus 19.8\%) or professional (56.6\% versus $49.2 \%$ ) occupations.

Also, in Table 2 are descriptive statistics relating to three dual career household types: 47 households in which neither partner has raised children; 33 households containing one or more dependent children and 50 that are either "empty nests" or contain non-dependent off-spring. As can be seen from the table, the 47, predominantly younger, households with no experience of child rearing, having the lowest average household income (2x£18.2), lowest job tenure and the highest household average number of hours paid employment - due largely to the significantly higher average working hours of the females in these households vis à vis the average hours of paid work reported by the females in the other households (41 versus approximately 35 hours per week). The other households generally consist of older couples, with higher average household earnings despite 
the fall in the hours and pay of the female partners. The differences between the households with and without experience of child rearing appear to indicate that:

a. The average pay and working hours of the male and female partners in households with no child rearing experience do not appear to be significantly different, particularly given the slightly older age and job tenure characteristics of the males relative to their female partners.

b. Large differences in terms of average pay and hours of work between the male and female partners appear in households with children. Total average household income is highest for this group because the high pay received by the males more than makes up for the significantly reduced pay associated with the female partners’ reduced work force participation rates.

c. A significant redistribution of within household career priorities appears to be indicated by the greatly increased earnings and working hours differentials towards the male partners in households with child rearing responsibilities. The results for the 50 empty nest households also suggest that this radical difference in the average pay and working hours of partners with child rearing duties, remains even after the child rearing duties have long ceased. 


\section{Empirical Hypotheses and Modelling}

The descriptive statistics shown in Table 2 are helpful in showing up several interesting differences between household characteristics and the pay and labour force participation differences within households. It is, however, clear that in order to isolate the impact of child rearing upon the relevant household and individual pay and labour market participation variables, a multivariate model will be required to provide an appropriate benchmark by which to sensibly evaluate any apparent deviations from “comparable” pay levels.

In empirical studies of relative pay levels, the market determined pay level of an individual is usually conceived to be a multiplicative function of their individual supply relevant (human capital) attributes, the demand relevant characteristics associated with their specific occupation, job and employer and their labour participation rate, i.e.,

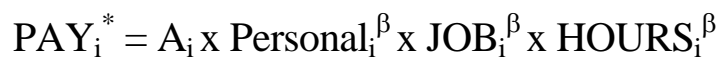

Typically, empirical models used to estimate relative pay levels across a sample of heterogeneous individuals have estimated a natural log version of (1) whereby individual i's logged pay is estimated as a linear function of the logged values of the number of hours worked, a vector of other job attributes and a vector of personal characteristics, i.e., 


$$
\log \left(\mathrm{PAY}_{\mathrm{i}}\right)=\log (\mathrm{a})+\beta \log \left(\mathrm{HOURS}_{\mathrm{i}}\right)+\Sigma \beta\left(\mathrm{JOB}_{\mathrm{i}}\right)+\Sigma \beta\left(\text { Personal }_{\mathrm{i}}\right)+\mathrm{u}_{\mathrm{i}}
$$

where, $\log \left(\mathrm{PAY}_{\mathrm{i}}\right)=\log$ of individual i's gross annual earnings from employment, $\log \left(\right.$ Hours $\left._{\mathrm{i}}\right)=\log$ of individual i’s number of total hours worked per annum, $\Sigma\left(\mathrm{JOB}_{\mathrm{i}}\right)=$ vector of demand-relevant occupational and sector dummy variables relating to individual i’s current job, $\Sigma\left(\right.$ Personal $\left._{\mathrm{i}}\right)=$ vector of supply-relevant labour market personal attributes relating to individual i, i.e., higher educational/professional qualifications, job tenure and age.

The model described in (2), which we label "Model 1", provides our 'gender blind' pay benchmark (i.e., the basis for evaluating our null hypothesis) for each individual. Our empirical analysis focuses on whether the explanatory power of "Model 1" can be improved upon by including additional gender, labour market participation rates (hours at work) and child rearing variables to the estimating equation. The alternative hypotheses are evaluated by augmenting full and sub-sample estimates of Model 1 with combinations of the above variables.

It is clear from the descriptive statistics presented in Table 2 that gender participation rates differ, particularly within households with children. This is confirmed by the regression estimates detailed in (3) below, whereby the LOG(HOURS) variable is regressed on the following 3 dummy variables: GENDER $=1$ if the individual concerned is female (and therefore GENDER $=0$, identifies the 
individual as a male); CHILD = 1 for all individuals in households that contain or have contained children; and, GENDER*CHILD =1 identifies only those women with children:

$$
\begin{gathered}
\log \left(\text { HOURS }_{\mathrm{i}}\right)=7.672+0.018 * \text { CHILD }-0.113 * \text { GENDER }-0.246 * \text { GENDER*CHILD }+\mathrm{u}_{\mathrm{i}} \\
(274.6)^{* * *}(0.43) \quad(2.48)^{* * *}
\end{gathered}
$$

Adjusted $\mathrm{R}^{2}=17.5 \% \quad$ F-Ratio $=19.3^{* * *}$

Notes: White (1980) Heteroskedasticity-Consistent t-values in parenthesis.

Significance levels: $* 0.10 ; \quad * * \leq 0.05 ; \quad * * * \leq 0.01$.

The average annual hours in paid employment of childless males is represented by the constant term, (which implies that childless males work approximately 2150 hours per annum, i.e., $\mathrm{e}^{7.672}=2150$ ). The above results indicate that male participation rates are essentially identical irrespective of whether or not they have children because the coefficient on the CHILD variable is statistically indistinguishable from zero. However, females without children are estimated to be in paid employment only $89.0 \%$ (i.e., the exponent of the coefficient on GENDER $=\mathrm{e}^{-0.113}=0.89$ ) of the hours worked by childless males. The large and statistically significant negative coefficient on the GENDER*CHILD variable shows that women with children have much lower participation rates than women without children. The estimated coefficient implies that they work only approximately $78 \%$ of the hours worked by women without children, i.e., $\mathrm{e}^{-0.246}=0.782$. Clearly the differential participation rate of women with children compared to men (with or without children) is much greater. The results suggest that women with children work slightly less than $70 \%$ of the hours worked by childless males (i.e., $\mathrm{e}^{-0.246-0.113}=0.698$ ). 
Career success (and high pay) typically requires (at least) full time participation and an absence of any extended career breaks. Hence, the differences in participation rates arising from gender imbalances in the distribution of child care responsibilities detailed in (3) can be expected to have a disproportionately negative impact upon the relative earnings of women with children. In terms of our pay level models, empirically this implies that the elasticity of pay with respect to the number of hours worked (the $\beta$ coefficient on the LOG(HOURS) variable) should be greater than unity for both males and females to reflect this "long-hours" culture associated with career building. However, the elasticity of pay with respect to hours worked should be even higher in the case of females particularly those with children and/or working part-time, since any career breaks or an inability to work full-time will have a significant negative effect upon career advancement and earnings opportunities.

Given the above, we empirically evaluate the following three hypotheses:

\section{H1: The Gender Factor (Model 1).}

Female pay levels will be significantly lower and the elasticity with respect to labour participation rates will be significantly higher than otherwise "comparable” males. However, due to equal pay rules that prohibit explicit discrimination on gender grounds, none of the other estimated coefficients in the pay model are expected to systematically differ between men and women. H1 is evaluated by estimating Model 1 three times (using data relating to both males and females, males only and females only) and then comparing the statistical significance of the differences in coefficient estimates. These results are shown in Table 3. 
By augmenting Model 1 with 2 new variables, CHILD and CHILD*LOG(HOURS), the following hypothesis may be evaluated:

H2: The Differential Parenting Factor (Models 2 and 3).

Male and Female (Model 2), or more likely only female (Model 3), pay levels in dual career households which contain (or have contained) one or more children will be lower (i.e., $\beta_{\mathrm{CHILD}}<0$ ) and the elasticity of their pay with respect to their labour participation rates will be higher than otherwise "comparable" males and females (i.e., $\beta_{\mathrm{CHILD*LOG(HOURS)}}>0$ ). The empirical results relating to the evaluation of $\mathrm{H} 2$ are shown in Table 4 and consist of three estimates of Model 2 using all observations, males only and females only. Also, included in Table 4 is Model 3 which uses all observations and includes a CHILD*GENDER dummy variable (to distinguish women with children from all other individuals) and a CHILD*GENDER*LOG(HOURS) variable to measure the differential elasticity of women with children's participation rates relative to all other individuals. This model explicitly tests whether the significantly lower participation rates of women with children leads to a more than proportionate decrease in their earnings levels vis à vis all other (male and female) individuals.

\section{H3: The Household-Type Factor.}

The gender factor suggested by $\mathrm{H} 1$ will be absent (or less apparent) in households without children but stronger for households with children if child-rearing duties lead to reduced participation rates and are largely responsible for the negative impact upon female pay. $\mathrm{H} 3$ is evaluated by comparing separately estimated versions of Model 1 and Model 4 (which includes the GENDER dummy 
variable and the GENDER*LOG(HOURS) variable) for households with children (CHILD=1) and without children (CHILD=0). Empirical support for H3 would imply that these 2 new gender variables will be significantly negative (i.e., $\beta_{\mathrm{GENDER}}<0$ ) and positive (i.e., $\beta_{\mathrm{GENDER} \text { (LOG(HOURS) }}>$ 0) respectively for the estimates using data from only households with children but insignificant in the estimates using only no child household observations. These estimates are shown in Table 5.

\section{Empirical Findings}

In Table 3, the empirical results relating to our gender-free pay determination model are presented using all observations and then separate estimates of male and female pay models are presented. Turning first to the Model 1 estimates using all observations, it is clear that the model is wellspecified in that the estimated parameters are all highly statistically significant, in the anticipated direction and that overall they explain a high proportion (over 83\%) of the cross-sectional variance in the pay levels of the individuals in the sample. As anticipated the age-wage profile appears to be of an inverted U-shape with the influence of age positive up to slightly over 50 years of age, after which age has a negative influence upon pay. Though educational/professional qualifications, job tenure and being in a managerial or professional occupation all increase pay, by far the most important influence upon pay appears to be the number of hours worked (exhibiting commitment, putting the job first). Moreover, the coefficient of 1.695 indicates that the elasticity of pay with respect to changes in the number of hours worked is very much more than unity, i.e., that high rates of pay per hour are associated with jobs which involve relatively high hours of work and, of course, vice versa. As anticipated the control variables relating to the individual's sector of employment 
indicate that individuals working in higher education or the public sector receive significantly less than individuals employed by private sector or interestingly NHS organizations (both nurses and doctors, including a number of consultants).

\section{Table 3}

The separately estimated male and female models are also shown in Table 3. As anticipated by H1, the "coefficient differences" column, shows that both the difference in the constant term and the participation rate are significantly different for men and women. Apart from the smaller coefficient (at 5\% confidence levels) associated with women working in managerial occupations, all of the other estimated coefficients in the separately estimated male and female models are statistically of identical magnitude, again as anticipated by H1. The highly statistically significant positive coefficient difference on the Log(HOURS) variable is important as it indicates a higher elasticity of female earnings relative to males of 0.634 , whose percentage change in earnings with respect to percentage changes in the number of hours worked is closer to unity (i.e., $\log (\mathrm{HOURS})=1.159$ ), Thus, increases (decreases) in the number of hours worked by females appears to have a disproportionately positive (negative) effect upon their pay levels, i.e., female pay is more highly geared than males with respect to the number of hours worked, thus highlighting the very significant negative impact that part-time working has on women’s careers and earnings opportunities.

The results of Model 2 and Model 3 are shown in Table 4 and it will be recalled that these models are included to empirically evaluate $\mathrm{H} 2$. Model 2 includes the 2 new variables that evaluate the 
influence that child rearing duties has upon earnings. The version of Model 2 estimated using the full sample of 260 individuals assumes unrealistically that the impact of child rearing upon partners earning is identical for both men and women. Nevertheless, as can be seen from the table, the addition of the new variables, CHILD and CHILD*LOG(HOURS) with negative and positive coefficients respectively, marginally increases the adjusted $\mathrm{R}^{2}$ of the estimates vis à vis Model 1 , and the F-ratio for the new variables is also marginally significant (at 10\% confidence levels). As was also evident from the gender analyses presented in Table 3, child rearing responsibilities appear to increase the elasticity of earnings with respect to differences in participation rates - though the effect is much smaller statistically than in the case of gender.

The separately estimated male and female versions of Model 2 are also shown in Table 4. It will be noted that the coefficients on the child rearing variables for the female estimates are both between 4 and 5 times as large as the male coefficient estimates which, as anticipated by H2, indicates that any child rearing effects upon earnings are far greater for females than for males. Indeed, the male coefficients on the child rearing variables are essentially zero. Table 4 also presents the estimates for Model 3 based on all 260 male and female observations. This model assumes that the earnings equation for females with child rearing responsibilities, who also generally have the lowest participation rate, differs from that of both other women and all males, but only in regard to the elasticity of earnings in respect of participation rates. The results show that this model increases the explanatory power of the empirical estimates vis à vis both Model 1 and Model 2 and that, as anticipated by $\mathrm{H} 2$, the coefficients on the 2 child rearing and participation variables are each individually statistically significant at $1 \%$ confidence levels. 
Finally, Table 5 presents empirical estimates of Model 1 and Model 4 by household type, i.e., those with children and those households that have never contained dependent children. Model 4 is simply Model 1 with the addition of the following 2 "gender" variables, GENDER (where 1=female and $0=$ male) and GENDER*Log(HOURS), an interaction term which measures the differential earnings elasticity of females relative to males with respect to the number of hours worked. As suggested by H3, it is expected that the earnings equation for males and females in no child households will be identical and that the addition of the gender variables will not have any significant impact on the explanatory power of the no child household Model 4 estimates vis à vis Model 1 (the gender-blind benchmark model). In contrast, H3 suggests that for the households with children there will be a marked gender difference in earnings equations and that the addition of the gender/participation rate variables will result in Model 4 having a significantly higher explanatory power vis à vis Model 1. As can be seen from the table, the empirical estimates confirm the above expectations. For the households with children, Model 4 results in an improved adjusted $\mathrm{R}^{2}$ vis à vis Model 1 and each of the 2 new variables are individually statistically significant at $1 \%$ confidence levels. For the households without children there is no evidence of any statistical difference between male and female earnings equations since the adjusted $\mathrm{R}^{2}$ of Model 4 declines vis à vis Model 1 and neither of the 2 new variables are of any statistical importance. Thus, statistically significant differences between male and female pay levels and in the elasticity of pay with respect to participation rates are only apparent in the case of households with children. What these results seem to indicate is that prioritising both careers in dual career households is not generally possible when the household includes dependent children and that the male partners' careers appears to 
'lead', and that differences remain even when age is controlled for. We now draw on more qualitative material for the sub-set of the 130 households who participated in follow-up in-depth interviews to provide additional insights into these results. In the interviews the lived reality of juggling work and home especially after childbirth was described. In some interviews factors external to the household (employer attitudes, child care provision, etc.) were mentioned as constraints while other interviewees emphasised factors internal to the household, such as problems of 'committing' to two careers and the division of the tasks of social reproduction.

Nineteen of the thirty households who participated in the in-depth interviews had children, and in 14 the female partner took either a career break or adjusted her working hours by working part-time. Only one male partner had taken a career break, and another was planning to (see below), while a number of other male partners took a few days of their holiday entitlement around the time of the birth of heir child. But most made no adjustment to their working pattern at the time of the birth and afterwards as Sarah ${ }^{4}$ emphasised in her interview, "James pursued his career as if we had no children, indeed as if he was still single, all the give has been on my part”.

Childbirth greatly increases the unpaid caring work associated with 'home', and a renegotiation of the tasks of social reproduction occurred first during maternity leave. One interviewee,

\footnotetext{
${ }^{4}$ James (self-employed consultant) and Sarah (university researcher) are both in their early fifties, have two grown up children, and have lived together for over 30 years. They met at school, they went to the same university (he was a couple of years ahead of her) and his job has always 'led' and as a result they have moved inter-regionally four times
} 
Becky ${ }^{5}$ was on maternity leave when she was interviewed, and while she intended to return to work she did express concern during the interview as to how she was going to juggle work and home at the end of her maternity leave. Prior to their child’s arrival Becky had done most of the unpaid work in the home, but she did emphasise that her partner, Gary also helped, “a lot”. On maternity leave she had slipped into a routine of having sole responsibility for childcare, and doing some of the tasks that Gary had done before she went on maternity leave, and acknowledged that she was making “a rod for my own back”. Like a number of other women interviewed, Becky commented that it was during a period of maternity leave that she started doing more and more household tasks and assumed responsibility for most childcare duties. When she does go back to work she thought it would be hard to break the pattern and share the household work more equitably. Moreover her job as a software consultant involves business trips away from home and she worried about how she would be able to do this because while Gary is a supportive partner this support would not extend to him having sole responsibility for the care of their son if she was away from the family home overnight on a business trip.

For some interviewees committing to children through a career break/working part-time for a spell was a conscious choice to enjoy motherhood; some commented that they could not see the point in having a child and then not 'being there' for them. For other women a career break/working part-time was the result of the gender division of labour in their household, they reduced their working hours as a coping strategy, and as such childbirth resulted in the

\footnotetext{
${ }^{5}$ Becky (software consultant) and Gary (accountant) are in their early 30s and met at university. They have a baby son and while they prioritise his career, until her maternity leave they both
} 
suppression of their personal aspirations. Claire ${ }^{6}$ for example, withdrew from the labour market for five years despite the fact that she had the largest salary, but in their 'traditional' household, Claire was prime carer, with little help from Ian. Once the children were old enough she started working part-time and now works full-time but on a fixed-term contract. Ian is keen they have a third child but Claire is not so keen as it would necessitate her giving up paid work again. They have had bad experiences with child minders, and this has been a cause of tension in the relationship. This is being exacerbated by what Claire sees as Ian's slow recognition of the responsibilities of being a parent although she does accept that he is beginning, “to grow into fatherhood”.

Only in a minority of households did both partners make career 'adjustments' for childcare. Both Nigel and Anne ${ }^{7}$ have taken time out to care for their daughter. Anne was prime carer for one year, "When I was pregnant with Becky, it was Nigel’s first child. He hated his job [social work] and I wanted to get back to work and it was an obvious solution. He really wanted to look after Becky”. Nigel said, "we actually role reversed as they call it...for me it was my first child, I felt that by going out to work I was missing out on something important”. He went on to say that, “we don’t particularly want both of us to be working full-time...the pressures attendant on two

worked very long hours

${ }^{6}$ Claire (senior social worker) and Ian (self-employed surveyor) are in their early forties and have been together since University days and have two teenage children. Ian's career has always 'led' ${ }^{7}$ Nigel (a part time lecturer with contracts with three employers) and Anne (a school teacher) are both in their early forties, and have been together for ten years. This is Anne's second marriage. Anne's two children from her first marriage live with them along with their eight year old daughter. Anne has the 'lead' career 
full-time careers would be enormous”. Both partners in another household ${ }^{8}$ are planning career adjustments for a child they hope to have. Samantha indicated that, "we will probably try and have children next year. I will take maternity leave...at the end of those six months Simon will apply for a career break [5 years]. He can't wait - seriously - he cannot wait to give up work”. In his interview Simon stressed he was feeling disillusioned with his current job.

A significant number of the women did talk at length about employer workplace-related issues. One older woman (in her 50s at the time of the interview) in an 'empty nester' household emphasised that when she was pregnant with her first child her employer had no maternity scheme, and women were expected to 'disappear'. Sarah resigned her post when she was pregnant, "you have to think back to 1969 /70 [when] the whole attitude to women with children working was very different. When I think back, women who graduated with me, quite a few of them got married and went [straight] into part-time jobs and never had full-time jobs. That was the social attitude you had in the Sixties”.

Since this time a whole array of equal opportunities legislation has given women statutory maternity rights (see Table 1). Studies of the impact of this legislation have indicated that it is women managers and professionals, like the ones who participated in this study, who have benefited the most. Indeed female managers and professionals in dual career households, who

\footnotetext{
${ }^{8}$ Simon (a Sales Executive) and Samantha (a Senior Analyst Programmer) are in their early thirties, and work full time for the same manufacturing company. They have been together for just over a decade, and met at work when they were both, 'on a fast-track general management scheme'
} 
are mothers, have a stronger attachment to the labour market after childbirth than do mothers in other households (McRae, 1997). Our quantitative analysis suggests that gender differences in career prioritisation remain when age is controlled for. One possible explanation is that for younger households, even those with egalitarian attitudes, it is the lived reality of new economy, of nonstandard employment contracts; unpredictable working hours and the long hours culture, that runs counter to these egalitarian principles. Cherie Booth regularly talks about the struggle she has in juggling home and work ${ }^{9}$ (Bunting, 2000). The reality of the new economy was certainly described in some interviews. Some men and women were employed on fixed term contracts as was university researcher Diana. ${ }^{10}$ “A year into my three year contract I became pregnant. I know that [the Head of Department] was most displeased. When he found out that I was entitled to maternity leave I think that upset him even more. He took the view that women are either a mother or a professional woman and you can't be both. He just felt that things were likely to become complicated where a woman had to juggle the responsibilities of a profession as well as looking after young children. He felt that the Department would be short-changed”.

\footnotetext{
${ }^{9}$ The Blair household is also assisted by paid domestic help

${ }^{10}$ Diana (mid 30s, university lecturer) and Bob (mid 40s, further education lecturer) met when

Diana was a student. They have a baby son and while they prioritise her career, they are very much equal partners. They employ a nanny to care for their son. Diana has held a series of fixed term contracts but now has a tenured lectureship.

${ }^{10}$ Becky (software consultant) and Gary (accountant) are in their early 30s and met at university. They have a baby son and while they prioritise his career, until her maternity leave they both worked very long hours
} 
She went on to say, "whilst I was pregnant I was doing more (work) than I should have done. I was taken into hospital for an emergency C-section because I developed hypertension. I'm sure it was all work-related, [due to] the stress that was on me really. I think words fail me when it comes to describing the pressures that were placed on me, not necessarily verbal. I suppose, like many women do who are pregnant or otherwise, we tend to over compensate and really work flat out. I suppose I was working flat out at a time in my life I shouldn't have been”. Diana has since moved to another university and has secured a tenured lectureship.

Some interviewees stressed that their jobs entail temporal and spatial flexibility and talked about the lived realities of uncertain working hours or the need to travel for business including nights away from the family home. The net result tended to be female partners rather than the male partners in our sample 'committing' less to work (and personal aspirations) after childbirth in an attempt to create a meaningful home life. Jane ${ }^{11}$ and Mark are an egalitarian household when it comes to decision making, but they both work unpredictable hours. While Jane works from a fixed base, Mark travels a lot within the country. When she first returned to work after maternity leave it was to her full-time post, but as Mark's hours were more unpredictable than hers, she was responsible for taking their child to nursery and collecting her on an evening. At work she used to get anxious that she would not be able to leave with sufficient time to travel to pick her daughter up before the nursery closed. As a food technologist she worked on a production line and could never exactly predict when her working day would end. The pressures of this

\footnotetext{
${ }^{11}$ Jane (food technologist) and Mark (sales representative) are in their mid-30s and have been together for about a decade. They have a young child who attends a private nursery
} 
uncertainty resulted in her switching to part-time (21 hours a week), with hours she feels are 'about right'. She did comment that her employer is "prejudiced against part-time work". Thus childbirth can impact negatively on career development often because employers and/or colleagues interpret a career break/part-time work as committing to home rather than to work (Epstein et al, 1999; Hochschild, 1997).

Finally, Joanne, ${ }^{12}$ a General Practitioner also talked about her decision to work part-time after the birth of her son. "The original agreement of the contract was that I would do half time until the child or children went to school and at that point I would have the option of going back fulltime if I wanted to. The average working week is 80 hours, I was not prepared to do that if I had a family, I didn't see the point in having children and leaving them with somebody else. I do 40 hours with the practice, the rest of the time I'm at home or doing my own thing, or doing paperwork for the practice, all this administrative stuff ... with nights and weekends it is 60 hours". Thus even though she is part-time the number of hours she devotes to the practice is 60 hours per week, considerably more hours per week than a typical full-time contract of 37 hours. Joanne created space for her family by working part-time. Joanne still is committed to her work, and certainly works more hours than she is contracted to work, but she also wants to commit to home. Ken her partner is a regional sales manager and his job entails a lot of travel, his car is his office and every week he spends some nights away from the family home. The reality of Ken's job is that he is not always around during the week to share in the running of the home. While 
most of the households have commodified some of the tasks of 'home' (cleaning etc), and use is also made of labour saving devices, it was the lack of quality of their home life following childbirth that caused a readjustment of working hours.

\section{Concluding Remarks}

The statistical results relating to the 130 dual career households along with the interview data tell a consistent story. Taken together, they provide strong empirical support for arguing that female participation rates fall when they have children and that their reduction in the number of hours in paid employment typically results in a disproportionate fall in their subsequent earnings levels. This disproportionate fall in earnings when participation rates are reduced clearly disadvantages women given the unequal distribution of domestic, particularly child rearing, duties within dual career households. Given the relationships between career progression and full-time and uninterrupted employment, it is not difficult to understand how for many women, even fairly short breaks away from work to attend to child rearing duties can often result in 'discontinuous careers', consisting of a series of relatively low paid and unchallenging, but convenient managerial and professional parttime jobs (Bonney and Love, 1991). Having children, however, tends to marginally increase the participation and earnings levels of males within such households whilst also having a significant depressive effect upon the earnings levels of females. This appears to be indicative of a household trade-off decision whereby the career of the male is given a higher priority and that of the female partner is (at least temporarily) sacrificed to some extent because of the need to 'be there' for children despite the use of childcare by some households.

\footnotetext{
${ }^{12}$ Joanne (doctor) and Ken (regional sales manager) are in their early forties and met about a decade ago when they both had established careers. Joanne has been married before. They have a five year old son at a private school and they employ a nanny 
The results provided in this paper also indicates that within household parity in terms of decisionmaking and career development is not the norm, particularly once childrearing duties have to be allocated. Although both partners attach importance to, and devote much energy to, pursuing their respective careers, in most households one career - generally the male career - tends to be prioritised; these are the very households that appear to 'individualise' the most as they adopt more 'traditional' gender roles (see also Dormsch and Ladwig, 1998).

Our results also appear to suggest that the lived reality of working in the new economy is adversely affecting the principles and practice of gender equity in those younger households that aspire to egalitarian relationships (Walby, 1995). Juggling two careers in the new economy, an environment with a long hours culture, and of intensified mobility, as well as trying to create a meaningful homelife in which to nurture children, appears to be impossible. This appears to be the case even in households with egalitarian principles, who offload some of the tasks of social reproduction to others through commodification. The working environment of the new economy appears to be perpetuating gendered career trajectories in 2002, and unless working patterns change for managers and professionals the pattern of female sacrifice is unlikely to change (Hochschild, 1997).

Working part-time or taking a career break though done for short-term 'convenience', in order to juggle 'work' and 'home' (such as wanting to prioritise home and be there for the children, moving to another part of the country/abroad for a partner's new job), is likely to significantly 
affect their long-term financial health, pension entitlements etc. Although recent changes in UK divorce law relating to splitting pensions could be seen as away of militating the negative effects of domestic duties that reduce women's earnings. 


\section{References}

Arber, S. (1999), 'Unequal partners: inequality in earnings and independent income within marriage', in S. Bowlby, S. Gregory and L. McKie (eds), Gender, Power and the Household (Basingstoke: Macmillian).

Beck, U. and E. Beck-Gernsheim (1995), The normal chaos of love (Cambridge: Polity Press).

Blossfeld, H-P. and S. Drobnic (eds) (2001), Careers of couples in contemporary societies (Oxford: Oxford University Press).

Bonney, N. and J. Love (1991), ‘Gender and migration: geographical mobility and the wife’s sacrifice’, Sociological Review, 39, 335-348.

Bruegel, I. (1996), 'The trailing wife: a declining breed? Careers, geographical mobility and household conflict in Britain 1970-89', in R. Crompton, D. Gallie and K. Purcell (eds), Changing Forms of Employment: organisations, skills and gender (London: Routledge).

Bunting, M. (2000), 'Taking the struggle out of family life’, The Guardian, 28 September,12

Court, G. (1995), 'Women in the Labour Market: two decades of continuity and change', Report 294 (Brighton, Institute of Employment Studies).

Deaux, K. and B. Major (1987), ' Putting gender into context: An interactive model of gender related behaviour', Psychological Review, 94, 369-389.

Dex, S. and Josh, H. (1999), 'Careers and motherhood: policies for compatibility', Cambridge Journal of Economics, 23,641-59

Dormsch, M.E. and D.H. Ladwig (1998), ‘Dual earner families’, European Network: Family and Work, 4/98 (Erkath: European Commission). 
Doyle, J. (2000), New Community of New Slavery: the emotional division of labour (London: The Industrial Society).

Drew, E. (1998), 'Changing family forms and the allocation of caring', in E. Drew, R. Emerek and E. Mahon (eds), Women, work and the family in Europe (London, Routledge).

Epstein, C. F., C. Seron, B. Oglensky and R. Sauté (1999), The part-time paradox: time norms, professional life, family and gender ( Routledge:New York).

Erikson, R. and J.H. Goldthorpe (1992), The constant flux: a study of class mobility in industrial societies (Oxford:Clarendon Press).

Evetts, J. (2000), ‘Analysing change in women’s careers: culture, structure and action dimensions', Gender, Work and Organization, 7,1, 57-67.

Folbre, N. (1994), Who pays for the kids? Gender and the structures of constraint (Routledge: London).

Ginn J and S. Arber (1995), 'Exploring mid-life women’s employment’, Work, Employment and Society, 29,1, 73-94

Gregson, N. and M. Lowe (1994), Servicing the Middle Classes: Class, gender and waged domestic labour in contemporary Britain (Routledge:London).

Hakim, C. (2000), Work-lifestyle choices in the $21^{\text {st }}$ century (Oxford, Oxford University Press).

Hanson, S. and G. Pratt (1995), Gender, Work and Space (Routledge, London).

Hardill, I., D.T. Graham and E. Kofman (2001), Human geography of the UK an introduction, (London:Routledge).

Hardill, I., A.E. Green, D.W. Owen, and A.C. Dudleston (1997), 'Who decides what? Decision making in dual career households', Work, Employment and Society, 11, 313-326. 
Hardill, I., A.C. Dudleston, A.E. Green, and D.W. Owen (1999), 'Decision-Making in Dual Career Households', in S. Bowlby , S. Gregory and L. McKie (eds) Gender, Power and the Household. (Basingstoke, Macmillian).

Hochschild, A. (1997), The time bind: when work becomes home and home becomes work (New York:Metropolitan Books).

Horrell, S. and J. Humphries (1995), 'Women's labour force participation and the transition to the male breadwinner family - 1790 - 1865’, Economic History Review, XLVIII, 89-117.

Jacobsen, J. P. (1994), The economics of gender (Oxford:Blackwell).

Jacobsen, J.P. and Rayack, W.L. (1996), ‘Do men whose wives work really earn less’, The American Economic Review, 86,2, 268-273

Jarvis, H., A.C. Pratt and P. Cheng-Chong Wu (2001), The Secret Life of Cities ( Harlow: Pearson).

McLaughlin, J. (1997), 'Feminist relations with postmodernism: reflections on the positive aspects of involvement', Journal of Gender Studies, 6,1,5-15

McKie, L., S.Bowlby and S. Gregory (1999), ‘ Connection gender, power and the household’, in (eds) L. McKie, S. Bowlby and S. Gregory Gender, Power and the Household ( MacMillan: Basingstoke).

McRae, S. (1997), 'Household and labour market change:implications for the growth of inequality in Britain', British Journal of Sociology, 48, 3, 384-405.

Mincer, J. (1978), ‘Family migration decisions’, Journal of Political Economy 86, 749-73.

Momsen, J. H. (1999), Gender, Migration and Domestic Service (London:Routledge). 
ONS and Equal Opportunities Commission (1998), Social Focus on Women and Men (London: HMSO).

Pahl, J. (1989), Money and Marriage (London:Macmillan).

Philliber, W.W. and D. Vannoy-Hillier (1990), 'The effects of husband’s occupational attainment on wife's achievement', Journal of Marriage and Family, 52,323-329.

Sizoo, E. (1997), Women's Lifeworlds: women's narratives on shaping their realities (London: Routledge).

Valentine, G. (1999), 'Doing household research:interviewing couples together and apart', Area, $31,1,67-74$.

Walby, S. (1995), Gender Transformations (London:Routledge).

Wheelock, J., S. Baines and E. Oughton (2000), 'Individual economic responsibility or social well-being? At the interface between economics and social policy',. Paper presented at EAPE 2000 Conference, Berlin.

White, H. 'A Heteroskedasticity-Consistent Covariance Matrix Estimator and a direct test for Heteroskedasticity', Econometrica, 48, 817-38. 


\section{Table 1}

\section{MATERNITY/PATERNITY RIGHTS IN THE UK}

- Maternity leave entitlement 18 weeks, not linked to length of service with employer. Receipt of Statutory Maternity Pay (SMP) payable for these18 weeks is dependent on working for employer for 26 weeks plus 15 weeks prior to expected delivery date and paying National Insurance contributions. Additional leave of up to 40 weeks with the right to return to work may also be taken but requires one year's continuous employment to qualify and applies only to mother.

- Maternity allowance for those employees not qualifying for SMP or who are self-employed.

- Maternity grant for those in receipt of state benefits.

- Parental leave may be taken, unpaid, by either parent but they must have one years continuous service with their employer, be the natural or adoptive parent, and give 21 days' notice to their employer. The child must be under 5 years of age. Up to 4 weeks may be taken in a year in periods of one week up to a total of 13 weeks over the 5year period for each child.

- Parents of disabled children may take time off in periods of one day if needed until the child is 18 years old.

- Emergency leave may be granted if there is a sudden breakdown in care arrangements.

Source: www.mymumworks.com 


\section{Table 2}

\section{Descriptive statistics of the 130 dual career households}

\begin{tabular}{|c|c|c|c|}
\hline Variable & MALES & FEMALES & AVERAGE \\
\hline AGE (respondent's age in years; n=130) & $42.2(8.5)$ & $40.2(8.2)$ & $41.2(8.4)$ \\
\hline AGE (no children; n=47) & $37.0(8.0)$ & $35.0(7.2)$ & $36.0(7.6)$ \\
\hline AGE (dependent children; n=33) & $42.2(7.4)$ & $41.8(6.9)$ & $42.0(7.1)$ \\
\hline AGE (empty nesters; n=50) & $47.0(6.7)$ & $44.0(7.3)$ & $45.5(7.2)$ \\
\hline PAY(current annual gross pay in $£ 000 ’ s ; n=130$ ) & $23.5(10.4)$ & $14.7(9.1)$ & $19.1(10.7)$ \\
\hline PAY (no children; n=47) & $19.9(8.7)$ & $16.5(7.8)$ & $18.2(8.4)$ \\
\hline PAY (dependent children; n=33) & 25.9 (9.3) & $13.7(9.7)$ & $19.8(11.4)$ \\
\hline PAY (empty nesters; n=50) & $25.6(9.5)$ & $13.8(9.8)$ & $19.7(11.3)$ \\
\hline HOURS (average hours per week at work; $n=130$ ) & $46.5(10.4)$ & $36.9(11.8)$ & 41.7 (12.1) \\
\hline HOURS (no children; n=47) & $45.6(9.4)$ & $41.0(9.1)$ & $43.3(9.5)$ \\
\hline HOURS(dependent children; n=33) & $46.9(11.3)$ & $35.4(13.3)$ & $41.2(13.6)$ \\
\hline HOURS (empty nesters; n=50) & $47.1(10.9)$ & $34.1(12.2)$ & $40.6(13.2)$ \\
\hline \multirow{2}{*}{$\begin{array}{l}\text { TENURE (time with current employer in years; } \\
\mathrm{n}=130 \text { ) }\end{array}$} & $6.6(6.9)$ & $4.7(5.3)$ & $5.6(6.2)$ \\
\hline & $4.6(6.0)$ & $3.0(4.5)$ & $3.8(5.3)$ \\
\hline TENURE (no children; n=47) & $5.6(5.6)$ & $5.5(6.1)$ & $5.6(5.8)$ \\
\hline TENURE (dependent children; n=33) & $9.3(7.7)$ & $5.6(5.2)$ & $7.4(6.8)$ \\
\hline \multicolumn{4}{|l|}{ TENURE (empty nesters; n=50) } \\
\hline Job Satisfaction ( $\%$ satisfied with job; $n=130$ ) & 92.0 & 92.0 & 92.0 \\
\hline JOBSAT (no children; n=47) & 89.0 & 91.0 & 90.0 \\
\hline JOBSAT(dependent children; n=33) & 94.0 & 85.0 & 89.0 \\
\hline JOBSAT (empty nesters; n=50) & 92.0 & 96.0 & 94.0 \\
\hline $\begin{array}{l}\text { QUAL (\% with a degree and /or professional } \\
\text { qualification) }\end{array}$ & 86.0 & 85.2 & \\
\hline HE SECTOR (\% employed in higher education sector) & 38.2 & 26.4 & \\
\hline PUBLIC SECTOR (\% employed in public sector) & 13.2 & 22.8 & \\
\hline MANAGERIAL (\% in managerial occupations) & 30.8 & 19.8 & \\
\hline PROFESSIONAL (\% in professional occupations) & 56.6 & 49.2 & \\
\hline
\end{tabular}

HOUSEHOLD

$\begin{array}{lll}\text { MALES } & \text { FEMALES } & \text { AVERAGE } \\ 42.2(8.5) & 40.2(8.2) & 41.2(8.4)\end{array}$

$37.0(8.0) \quad 35.0(7.2) \quad 36.0(7.6)$

$42.2(7.4) \quad 41.8(6.9) \quad 42.0(7.1)$

$23.5(10.4) \quad 14.7(9.1) \quad 19.1(10.7)$

$19.9(8.7) \quad 16.5(7.8) \quad 18.2(8.4)$

$25.9(9.3) \quad 13.7(9.7) \quad 19.8(11.4)$

$46.5(10.4) \quad 36.9(11.8) \quad 41.7 \quad(12.1)$

$45.6(9.4) \quad 41.0(9.1) \quad 43.3(9.5)$

$46.9(11.3) \quad 35.4(13.3) \quad 41.2(13.6)$

$6.6(6.9) \quad 4.7(5.3) \quad 5.6(6.2)$

$4.6(6.0) \quad 3.0(4.5) \quad 3.8(5.3)$

$5.6(5.6) \quad 5.5(6.1) \quad 5.6(5.8)$

$9.3(7.7) \quad 5.6(5.2) \quad 7.4(6.8)$

$\begin{array}{lll}92.0 & 92.0 & 92.0\end{array}$

$\begin{array}{lll}89.0 & 91.0 & 90.0\end{array}$

$\begin{array}{lll}94.0 & 85.0 & 89.0\end{array}$

$\begin{array}{lll}92.0 & 96.0 & 94.0\end{array}$

85.2

26.4

49.2 


\section{Table 3}

\section{Benchmark Pay Level Model and Gender Difference Results}

\begin{tabular}{|c|c|c|c|c|}
\hline Variable & $\begin{array}{l}\text { Model } 1 \\
(n=260)\end{array}$ & $\begin{array}{c}\text { Males } \\
(n=130)\end{array}$ & $\begin{array}{l}\text { Females } \\
(n=130)\end{array}$ & $\begin{array}{l}\text { Coefficient } \\
\text { Differences }\end{array}$ \\
\hline constant & $\begin{array}{l}-4.903 \\
(7.13)^{* * *}\end{array}$ & $\begin{array}{l}-1.482 \\
(0.99)\end{array}$ & $\begin{array}{l}-5.168 \\
(6.98)^{* * *}\end{array}$ & $\begin{array}{l}-3.686 \\
(2.21)^{* *}\end{array}$ \\
\hline AGE & $\begin{array}{l}0.060 \\
(3.25)^{* * *}\end{array}$ & $\begin{array}{l}0.088 \\
(3.52)^{* * *}\end{array}$ & $\begin{array}{r}0.039 \\
(1.57)\end{array}$ & $\begin{array}{r}-0.049 \\
(1.39)\end{array}$ \\
\hline $\mathrm{AGE}^{2}$ & $\begin{array}{l}-0.597 \mathrm{E}-3 \\
(2.83)^{* * *}\end{array}$ & $\begin{array}{l}-0.817 \mathrm{E}-3 \\
(2.88)^{* * *}\end{array}$ & $\begin{array}{l}-0.389 \mathrm{E}-3 \\
(1.37)\end{array}$ & $\begin{array}{l}0.427 \mathrm{E}-3 \\
(1.06)\end{array}$ \\
\hline LOG(HOURS) & $\begin{array}{c}1.695 \\
(20.17)^{* * *}\end{array}$ & $\begin{array}{l}1.159 \\
(6.06)^{* * *}\end{array}$ & $\begin{array}{l}1.792 \\
(25.11)^{* * *}\end{array}$ & $\begin{array}{l}0.634 \\
(3.10)^{* * *}\end{array}$ \\
\hline LOG(TENURE) & $\begin{array}{l}0.048 \\
(2.63)^{* * *}\end{array}$ & $\begin{array}{l}0.255 \mathrm{E}-3 \\
(0.01)\end{array}$ & $\begin{array}{l}0.059 \\
(2.37)^{* *}\end{array}$ & $\begin{array}{l}0.059 \\
(1.54)\end{array}$ \\
\hline QUAL & $\begin{array}{c}0.263 \\
(4.81)^{* * *}\end{array}$ & $\begin{array}{l}0.195 \\
(2.53)^{* * *}\end{array}$ & $\begin{array}{l}0.314 \\
(4.19)^{* * *}\end{array}$ & $\begin{array}{c}0.118 \\
(1.10)\end{array}$ \\
\hline HE SECTOR & $\begin{array}{l}-0.171 \\
(3.55)^{* * *}\end{array}$ & $\begin{array}{l}-0.192 \\
(3.14)^{* * *}\end{array}$ & $\begin{array}{l}-0.237 \\
(3.45)^{* * *}\end{array}$ & $\begin{array}{l}-0.045 \\
(0.49)\end{array}$ \\
\hline PUBLIC SECTOR & $\begin{array}{l}-0.255 \\
(4.85)^{* * *}\end{array}$ & $\begin{array}{l}-0.390 \\
(4.07)^{* * *}\end{array}$ & $\begin{array}{l}-0.241 \\
(3.51)^{* * *}\end{array}$ & $\begin{array}{l}0.149 \\
(1.27)\end{array}$ \\
\hline MANAGERIAL & $\begin{array}{l}0.188 \\
(3.13)^{* * *}\end{array}$ & $\begin{array}{l}0.320 \\
(3.48)^{* * *}\end{array}$ & $\begin{array}{r}0.063 \\
(0.84)\end{array}$ & $\begin{array}{l}-0.257 \\
(2.15)^{* *}\end{array}$ \\
\hline PROFESSIONAL & $\begin{array}{l}0.224 \\
(3.64)^{* * *}\end{array}$ & $\begin{array}{l}0.350 \\
(3.32)^{* * *}\end{array}$ & $\begin{array}{l}0.190 \\
(2.68)^{* * *}\end{array}$ & $\begin{array}{l}-0.160 \\
(1.26)\end{array}$ \\
\hline ADJUSTED R ${ }^{2}$ & $83.4 \%$ & $68.6 \%$ & $87.3 \%$ & $85.1 \%$ \\
\hline Equation F RATIO & $145.4^{* * *}$ & $32.3^{* * *}$ & $99.6 * * *$ & $79.0 * * *$ \\
\hline F-ratio for New Variables & N/A & N/A & N/A & $3.94 * * *$ \\
\hline
\end{tabular}

Notes:

White (1980) Heteroskedasticity-Consistent t-values in parenthesis.

Significance levels: $* \leq 0.10 ; \quad * * \leq 0.05 ; \quad * * * \leq 0.01$.

F-ratio for New Variables and significance levels computed relative to Model 1.

Coefficient Differences statistics computed from augmenting Model 1 with a gender dummy variable and gender interaction terms of each of the Model 1 independent variables. 


\section{Table 4}

\begin{tabular}{|c|c|c|c|c|}
\hline \multicolumn{5}{|c|}{ Gender and Households with Children Relationships } \\
\hline Variable & $\begin{array}{c}\text { Model } 2 \\
(\mathrm{n}=260)\end{array}$ & $\begin{array}{c}\text { Males } \\
(n=130)\end{array}$ & $\begin{array}{l}\text { Females } \\
(n=130)\end{array}$ & $\begin{array}{l}\text { Model } 3 \\
(n=260)\end{array}$ \\
\hline constant & $\begin{array}{l}-2.758 \\
(2.10)^{* *}\end{array}$ & $\begin{array}{l}-0.985 \\
(0.53)\end{array}$ & $\begin{array}{l}-3.327 \\
(2.00)^{* *}\end{array}$ & $\begin{array}{l}-2.529 \\
(2.02)^{* *}\end{array}$ \\
\hline AGE & $\begin{array}{l}0.060 \\
(3.28)^{* * *}\end{array}$ & $\begin{array}{l}0.081 \\
(3.14)^{* * *}\end{array}$ & $\begin{array}{c}0.038 \\
(1.58)\end{array}$ & $\begin{array}{l}0.067 \\
(3.80)^{* * *}\end{array}$ \\
\hline $\mathrm{AGE}^{2}$ & $\begin{array}{l}-0.599 \mathrm{E}-3 \\
(2.90)^{* * *}\end{array}$ & $\begin{array}{l}-0.756 \mathrm{E}-3 \\
(2.63)^{* * *}\end{array}$ & $\begin{array}{l}-0.381 \mathrm{E}-3 \\
(1.36)\end{array}$ & $\begin{array}{l}-0.640 \mathrm{E}-3 \\
(3.24)^{* * *}\end{array}$ \\
\hline LOG(HOURS) & $\begin{array}{c}1.412 \\
(8.61)^{* * *}\end{array}$ & $\begin{array}{l}1.112 \\
(4.83)^{* * *}\end{array}$ & $\begin{array}{l}1.548 \\
(7.66)^{* * *}\end{array}$ & $\begin{array}{l}1.366 \\
(8.23)^{* * *}\end{array}$ \\
\hline LOG(TENURE) & $\begin{array}{l}0.045 \\
(2.44)^{* * *}\end{array}$ & $\begin{array}{l}0.317 \mathrm{E}-3 \\
(0.11)\end{array}$ & $\begin{array}{l}0.058 \\
(2.30)^{* *}\end{array}$ & $\begin{array}{l}0.039 \\
(2.08)^{* *}\end{array}$ \\
\hline QUAL & $\begin{array}{c}0.272 \\
(4.89)^{* * *}\end{array}$ & $\begin{array}{l}0.202 \\
(2.57)^{* * *}\end{array}$ & $\begin{array}{c}0.324 \\
(4.18)^{* * *}\end{array}$ & $\begin{array}{l}0.246 \\
(4.52)^{* * *}\end{array}$ \\
\hline HE SECTOR & $\begin{array}{l}-0.169 \\
(3.50)^{* * *}\end{array}$ & $\begin{array}{l}-0.181 \\
(2.99)^{* * *}\end{array}$ & $\begin{array}{l}-0.238 \\
(4.18)^{* * *}\end{array}$ & $\begin{array}{l}-0.188 \\
(4.02)^{* * *}\end{array}$ \\
\hline PUBLIC SECTOR & $\begin{array}{l}-0.240 \\
(4.46)^{* * *}\end{array}$ & $\begin{array}{l}-0.369 \\
(3.59)^{* * *}\end{array}$ & $\begin{array}{l}-0.230 \\
(3.29)^{* * *}\end{array}$ & $\begin{array}{l}-0.280 \\
(5.35)^{* * *}\end{array}$ \\
\hline MANAGERIAL & $\begin{array}{l}0.187 \\
(3.14)^{* * *}\end{array}$ & $\begin{array}{l}0.314 \\
(3.34)^{* * *}\end{array}$ & $\begin{array}{r}0.069 \\
(0.92)\end{array}$ & $\begin{array}{l}0.182 \\
(3.18)^{* * *}\end{array}$ \\
\hline PROFESSIONAL & $\begin{array}{l}0.227 \\
(3.69)^{* * *}\end{array}$ & $\begin{array}{l}0.349 \\
(3.27)^{* * *}\end{array}$ & $\begin{array}{l}0.184 \\
(2.56)^{* * *}\end{array}$ & $\begin{array}{l}0.233 \\
(3.97)^{* * *}\end{array}$ \\
\hline CHILD & $\begin{array}{l}-2.556 \\
(1.87)^{*}\end{array}$ & $\begin{array}{l}-0.465 \\
(0.21)\end{array}$ & $\begin{array}{l}-2.178 \\
(1.30)\end{array}$ & \\
\hline CHILD*LOG(HOURS) & $\begin{array}{c}0.340 \\
(1.87)^{*}\end{array}$ & $\begin{array}{r}0.069 \\
(0.23)\end{array}$ & $\begin{array}{r}0.291 \\
(1.33)\end{array}$ & \\
\hline CHILD*GENDER & & & & $\begin{array}{l}-3.530 \\
(2.60)^{* * *}\end{array}$ \\
\hline CHILD*GENDER*LOG(HOURS) & & & & $\begin{array}{l}0.455 \\
(2.57)^{* * *}\end{array}$ \\
\hline ADJUSTED $\mathrm{R}^{2}$ & $83.6 \%$ & $68.3 \%$ & $87.4 \%$ & $84.6 \%$ \\
\hline Equation F RATIO & $121.2^{* * *}$ & $26.3 * * *$ & $82.1 * * *$ & $130.2^{* * *}$ \\
\hline F-ratio for New Variables & $2.83 *$ & 0.53 & 1.25 & $11.1^{* * *}$ \\
\hline
\end{tabular}

Notes: White (1980) Heteroskedasticity-Consistent t-values in parenthesis.

Significance levels: $* \leq 0.10 ; * * \leq 0.05 ; * * * \leq 0.01$.

F-ratio for New Variables and significance levels computed relative to Model 1.

The dummy variable CHILD = 1 for individuals in "Households with Children". The "Households with Children" sub-sample consists of the 33 "dependent children" and the 50 "empty nester" households. 
Table 5

Analyses By Household Type (Households with Children/No Children)

\begin{tabular}{|c|c|c|c|c|}
\hline Variable & Model 1 & Model 4 & Model 1 & Model 4 \\
\hline \multirow[t]{2}{*}{ constant } & -5.302 & -1.587 & -2.607 & -1.338 \\
\hline & $(7.15)^{* * *}$ & $(0.86)$ & $(1.92)^{*}$ & $(0.74)$ \\
\hline \multirow[t]{2}{*}{ AGE } & 0.060 & 0.053 & 0.038 & 0.040 \\
\hline & $(2.44) * *$ & $(2.39) * *$ & $(1.16)$ & $(1.22)$ \\
\hline \multirow[t]{2}{*}{$\mathrm{AGE}^{2}$} & $-0.625 \mathrm{E}-3$ & $-0.520 \mathrm{E}-3$ & $0.292 \mathrm{E}-3$ & $0.320 \mathrm{E}-3$ \\
\hline & $(2.29) * *$ & $(2.16)^{* *}$ & $(0.73)$ & $(0.80)$ \\
\hline \multirow[t]{2}{*}{ LOG(HOURS) } & 1.749 & 1.296 & 1.459 & 1.292 \\
\hline & $(17.84)^{* * *}$ & $(5.53)^{* * *}$ & $(9.34)^{* * *}$ & $(5.59)^{* * *}$ \\
\hline \multirow[t]{2}{*}{ LOG(TENURE) } & 0.026 & 0.010 & 0.078 & 0.071 \\
\hline & $(1.24)$ & $(0.43)$ & $(2.20)^{* *}$ & $(2.20)^{* *}$ \\
\hline \multirow[t]{2}{*}{ QUAL } & 0.282 & 0.263 & 0.191 & 0.191 \\
\hline & $(4.66)^{* * *}$ & $(4.39) * * *$ & (1.37) & $(1.89)^{*}$ \\
\hline \multirow[t]{2}{*}{ HE SECTOR } & -0.141 & -0.168 & -0.224 & -0.229 \\
\hline & $(2.38)^{* * *}$ & $(2.89) * * *$ & $(2.87) * * *$ & $(2.79)^{* * *}$ \\
\hline \multirow[t]{2}{*}{ PUBLIC SECTOR } & -0.212 & -0.255 & -0.309 & -0.317 \\
\hline & $(2.86)^{* * *}$ & $(3.29)^{* * * *}$ & $(4.55)^{* * *}$ & $(4.69) * * *$ \\
\hline \multirow[t]{2}{*}{ MANAGERIAL } & 0.237 & 0.219 & 0.086 & 0.083 \\
\hline & $(3.03)^{* * *}$ & $(2.92)^{* * *}$ & $(0.96)$ & $(0.92)$ \\
\hline \multirow[t]{2}{*}{ PROFESSIONAL } & 0.262 & 0.267 & 0.150 & 0.162 \\
\hline & $(3.18)^{* * *}$ & $(3.43)^{* * *}$ & $(1.72)^{*}$ & $(1.76)^{*}$ \\
\hline \multirow[t]{2}{*}{ GENDER } & & -4.100 & & -1.902 \\
\hline & & $(2.21)^{* *}$ & & $(0.79)$ \\
\hline \multirow[t]{2}{*}{ GENDER*LOG(HOURS) } & & 0.523 & & 0.248 \\
\hline & & $(2.18)^{* *}$ & & $(0.79)$ \\
\hline ADJUSTED R ${ }^{2}$ & $87.6 \%$ & $89.0 \%$ & $61.7 \%$ & $61.1 \%$ \\
\hline Equation F RATIO & $130.4 * * *$ & $122.4 * * *$ & $17.7 * * *$ & $14.3^{* * *}$ \\
\hline F RATIO for New Variables & N/A & $11.0 * * *$ & N/A & 0.3 \\
\hline \multicolumn{5}{|c|}{ Notes: } \\
\hline \multicolumn{5}{|c|}{ White (1980) Heteroskedasticity-Consistent t-values in parenthesis. } \\
\hline \multicolumn{5}{|c|}{ Significance levels: $*<=0.10 ; \quad * *<=0.05 ; \quad * * *<=0.01$} \\
\hline \multicolumn{5}{|c|}{ F-ratio for New Variables and significance levels computed relative to Model 1.} \\
\hline \multicolumn{5}{|c|}{$\begin{array}{l}\text { The "Households with Children” sub-sample consists of the } 33 \text { “dependent children” and the } 50 \\
\text { "empty nester" households. }\end{array}$} \\
\hline
\end{tabular}

Households with Children No Child Households $(n=166)$

$(7.15)^{* * *}$

(0.86)

0.053

$-0.520 \mathrm{E}-3$

-0.625E-3

$(2.29)^{* *}$

$(2.16)^{* *}$

$(5.53) * * *$

1.292

$(17.84)^{* * *}$

0.010

$(0.43)$

0.263

$(4.39)^{* * *}$

$(2.89) * * *$

$-0.255$

$(3.29)^{* * *}$

$(2.92)^{* * *}$

(0.96)

(0.92)

0.262

(3.43)*

0.150

0.162

$-1.902$

(0.79)

$(2.21)^{* *}$

0.248

$(2.18)^{* *}$

$61.1 \%$

Equation F RATIO

$130.4^{* * *}$

$11.0 * * *$

N/A 